\title{
STUDY THE EFFECT OF THE ENVIRONMENTAL PARAMETERS ON THE PERFORMANCE OF A PROTOTYPE FOR ASPHALT SOLAR COLLECTOR USING AIR AS A WORKING FLUID
}

\author{
Kaddah, K.Sh. ${ }^{(1)}$; Hewhy, M. A. ${ }^{(2)}$; Selim, A. ${ }^{(3)}$; Saad, H. ${ }^{(1)}$ \\ and Ramadan, A. M. ${ }^{(4)}$ \\ 1) Faculty of Engineering, Ain Shams University 2) Institute of \\ Environmental Studies and Research Ain Shams University 3) Ministry of \\ Transportation 4) Rashid Company for Oil and Gas
}

\begin{abstract}
Diminution of fossil fuel inspires researches to look for renewable energy sources. Heat island and road accidents resulted from tires explosion due to excessive asphalt heat (reach to $70{ }^{\circ} \mathrm{C}$ ) were another problems. These problems oriented researchers to use asphalt as a heat collector. They found by using asphalt as a heat collector it will gain energy, reduce heat island and reduce road accidents as well. Recently researchers started to use some applications of asphalt solar collector (ASC). Majority of these applications used to heat and cool water. In this research, the first ASC prototype was built outside the laboratory and using atmospheric air as a working fluid. The environmental parameters such as ambient temperature, variation of solar day time, asphalt surface temperature is considered. This prototype consisted of buried pipes under asphalt layers with two opening ends. One end is connected to atmospheric air duct and the other ends connected to Unplasticized Poly Vinyl Chloride (UPVC) chimney. It has been found compatibility with the laboratory study in the strong effect of the chimney height on the air flow velocity through the ASC. Also it can be concluded that the ASC prototype performance for producing energy depends on prototype components in terms of chimney height, asphalt temperature and the environmental / atmospheric conditions in terms of ambient air temperature, and ambient wind speed.
\end{abstract}

Key words: Asphalt collector, solar energy, energy harvesting, and air velocity. 
J. Environ. Sci.

Institute of Environmental Studies and Research - Ain Shams University

\section{INTRODUCTION}

Increasing the fossil fuel consumption has resulted in increasing greenhouse gas emissions to the atmosphere which led to increase global warming. In order to reduce these effects many researches and new alternative energy generation methods are promoted. Such methods provide renewable, clean, and sustainable development of the environment. (Philibert, 2011). In 90 minutes, enough sunlight strikes the earth to provide the entire planet's energy needed for one year. While solar energy is abundant, it represents a small portion of the world's current energy mix. But this is changing rapidly and is being driven by global action to improve energy access and supply security. Many Researches was founded to develop a system of converting energy absorbed by asphalt from sun to a reusable energy resource (Sullivan, 2007). One application to use solar energy is Asphalt Solar Collector (ASC). Pavements working as ASC often consist of a porous surface or a serpentine embedded with a circulating fluid in the pavement.

ASC needs a surface with an ability to transport heat and very high absorptivity. For example, using a flow of fluids, and the flow regime inside the serpentine has to be turbulent to reach the maximum efficiency. Furthermore, from previous researches it has been recommended that the pipes used in the serpentine should be made of high thermal conductivity metal like copper (Mallick RB, 2009) (Pascual-Munoz P, 2013). Also asphalt pavements has a high absorptivity which can be heated up to $343 \mathrm{~K}\left(70{ }^{\circ} \mathrm{C}\right)$ by solar radiation during the summer (Al-Saad, 1994) 
In addition, this type of collectors will be in risk of being damaged as a result it cannot be constructed in roads with high traffic intensities and loads (Bobes-Jesus V, 2012). Moreover, a maintenance problem may present in these roads, as in case the asphalt cracking it may be difficult to repair (Wang H, 2010) . On the other hand, solar chimneys are a special type of solar collector which consists of a very high absorptivity air heating system connected to an updraft tube (Sakonidou EP, 2008). Due to sun irradiation, the air inside the ASC pipes will be heated, as a result, convection causes the air density to decreased, creating an updraft air through the chimney which allows wind turbines to produce electricity (Fluri, 2008) . Furthermore, through some buildings this air flow may be also used to enhance the ventilation properties through these buildings (Riain, 1999) . But these systems have an inherit problem of having a very low efficiency for producing electric power.

Therefore, the objective of this study is to investigate the effect of chimney height on the performance of ASC using air as a working fluid. For that purpose an aluminum tubes were embedded in an asphalt concrete material and a PVC pipes has been simulated for the chimney. The air mass flow rates and the asphalt temperature have been considered as an indicator for the energy gain by the asphalt.

\section{EXPERIMENTAL METHOD}

Figures 1 and 2 illustrate image and layout of the test rig used in this investigation. The test rig is a prototype ASC and was tested in Cairo, Egypt where irradiance levels year round ranges from 3.2 to $8.1 \mathrm{kWh} / \mathrm{m} 2$ /day with 
an annual average of $5.9 \mathrm{kWh} / \mathrm{m} 2$ /day on a horizontal surface and from 4.9 to $7.3 \mathrm{kWh} / \mathrm{m} 2$ /day with an annual average $6.48 \mathrm{kWh} / \mathrm{m} 2$ /day for optimally tilted surface (Shouman, 2016). A $150 \mathrm{Kg}$ asphalt solid concrete mixture AC4 with 70/100 virgin bitumen was used and placed inside a wooden frame as shown in Figure 1. The asphalt mixture with bitumen was used in this research. The aggregates consisted of crushed basaltic material (size between $4 \mathrm{~mm}$ and nominal maximum aggregate size of $8 \mathrm{~mm}$ with average density $2870 \mathrm{~kg} / \mathrm{m}^{3}$ ), 0.063 and $2 \mathrm{~mm}$ crushed sand with density $2670 \mathrm{~kg} / \mathrm{m}^{3}$ and $0.063 \mathrm{~mm}$ filler with density $2598 \mathrm{~kg} / \mathrm{m}^{3}$. The asphalt absorptivity is equal to 0.87 at $300 \mathrm{~K}$.

The air pass were created through 36 tubes embedded in the mixture. Aluminum pipes were used in this research as shown in Figure (1). Each pipe is $1 \mathrm{~m}$ long with $12 \mathrm{~mm}$ inner diameter, and $0.9 \mathrm{~mm}$ thick. All pipes were placed at one level in the horizontal direction placed at $2.5 \mathrm{~cm}$ from asphalt surface layer while the asphalt layer thickness is $10 \mathrm{~cm}$.

All pipes are arranged in parallel. This will keep the system running even if one or more pipes are broken.

Moreover, the asphalt concrete prototype upper surface was exposed to the sun light which was the solar energy source. The upper surface area of the ASC was $1 \mathrm{~m} \mathrm{X} \mathrm{1m.} \mathrm{Besides,} 10 \mathrm{~cm}$ X $10 \mathrm{~cm}$ X $1 \mathrm{~m}$ two air chambers sealed with epoxy resin were established at both sides of the test model at the inlet and the outlet of the air pipes to ensure that the entrained air could circulate through the entire asphalt layer as shown in Fig. (1). A hole of $5 \mathrm{~cm}$ diameter was opened in the end of the outlet air chamber to be equipped with a 
chimney constructed of 4" UPVC pipe with two different heights 4 , and $9 \mathrm{~m}$ respectively.

As the ASC exposed to the solar energy, the heat is transferred to the asphalt layer. In this case the buried pipes are heated by conduction; while heat is transferred to the inside air by convection. As the air is heated up, the air density decreases causing the air to flow up and draft through the chimney, due to density difference. An air anemometer is used to measure the velocity of air inside the chimney. The anemometer is placed at the end of the chimney.

In addition to measure the inlet and outlet drafted air temperatures a compact digital thermometer is used. The digital thermometer type is TPM30 and has a range of $-50{ }^{\circ} \mathrm{C}:+70{ }^{\circ} \mathrm{C}$ with a resolution $>-20{ }^{\circ} \mathrm{C}, 0.1{ }^{\circ} \mathrm{C}$; $\leq-$ $20^{\circ} \mathrm{C}, 1{ }^{\circ} \mathrm{C}$ and an accuracy $\pm 1{ }^{\circ} \mathrm{C}$.

The surface temperature of the buried tubes is measured using an infrared thermometer. The infrared thermometer type is (MIR300) and has a range of $20{ }^{\circ} \mathrm{C}$ : $320{ }^{\circ} \mathrm{C}$, Resolution $0.1{ }^{\circ} \mathrm{C}, 1{ }^{\circ} \mathrm{C}$, and Accuracy $\pm 2{ }^{\circ} \mathrm{C}$.

All tests took place in different atmospheric conditions as the prototype is located outside. As a result, this setup was used to investigate the relationship between various environmental parameters such as ambient wind speed, ambient air temperature as well as, varies configurations of the ASC prototype such as chimney height and asphalt surface temperature. 


\section{THEORETICAL BACKGROUND}

As the asphalt concrete exposed to the sun radiation the heat is absorbed to the asphalt surface causing its temperature to increase. The absorbed radiation from sun to the asphalt concrete can be calculated as:

$$
\mathrm{q}_{\text {solar }}=\alpha \mathrm{I},
$$

Where $\mathrm{q}_{\text {solar }}$ is the total radiation absorbed by asphalt concrete in $\mathrm{W} / \mathrm{m}^{2} ; \alpha$ is the asphalt absorptivity to sun solar radiation and $\mathrm{I}$ is the sun solar intensity.

Also the heat transferred to the asphalt concrete increasing the surface temperature which increasing the thermal radiation emitted to the environment. This emitted heat transfer can be calculated as:

$$
\mathrm{q}_{\mathrm{emitted}}=\sigma \varepsilon\left(\mathrm{T}_{\mathrm{s}}^{4}-\mathrm{T}_{\mathrm{a}}{ }^{4}\right)
$$

Where $\mathrm{q}_{\mathrm{emitted}}$ is the emitted radiation to the environment in $\mathrm{W} / \mathrm{m}^{2}, \sigma$ is the Stefan-Boltzmann constant which equal to $5.67 \times 10^{-8} \mathrm{~W} / \mathrm{m}^{2} \mathrm{~K}, \varepsilon$ is the emissivity of the asphalt concrete, and $T_{s}$ is the surface temperature of the asphalt layer in $K$, while $T_{a}$ is the atmospheric temperature in $K$.

Furthermore, there is another mode of heat loss from the asphalt surface to the atmospheric air by natural convection as shown in fig. $2 \mathrm{~b}$ and calculated using the following equation.

$$
\mathrm{q}_{\mathrm{c}}=\mathrm{h}_{\mathrm{S}}\left(\mathrm{T}_{\mathrm{s}}-\mathrm{T}_{\mathrm{a}}\right)
$$

Where $h_{s}$ is the mean heat transfer coefficient by convection between the asphalt surface and the environment air $\mathrm{W} / \mathrm{m}^{2} \mathrm{~K}$. The heat transfer coefficient can be calculated by the following equation as deduced by (Hsieh C K, 1989) (Simulation, 2007). 
$\mathrm{h}_{\mathrm{s}}=698.24\left(0.00144\left(\left(\mathrm{t}_{\mathrm{l}}+\mathrm{t}_{\mathrm{a}}\right) / 2+273.15\right)^{0.3} \mathrm{v}^{0.7}+0.00097\left(\mathrm{t}_{\mathrm{l}}-\mathrm{t}_{\mathrm{a}}\right)^{0.3}\right)$

Where $\mathrm{v}$; is the wind velocity over the asphalt surface.

The heat is then transferred and distributed along the asphalt concrete by conduction. After that, the heat is transferred to the air inside the tubes by natural convective as shown in Fig. $2 \mathrm{~b}$. As a result, the temperature gradient with the asphalt depth will affect the efficiency of the air flow at the tubes and the inlet air temperature to the chimney, $T_{i}$ as well. The inlet air temperature to the chimney will be less than the asphalt surface temperature as detected in figure (3).

The calculation can be simplified in this research by considering the temperature of the asphalt to be constant and equal to the surface temperature of the asphalt, $T_{\mathrm{s}}$. Now the heat is transferred to the flowing air inside the tubes by convection causing the air temperature to increase at the end of the tube before enter the chimney and this heat can be calculated from the following equation,

$$
\mathrm{q}_{\text {conection-air }}=\mathrm{h}_{\text {in }} \mathrm{A}_{\text {tube }}\left(\mathrm{T}_{\text {tube }}-\mathrm{T}_{\mathrm{av}}\right)
$$

Where, $\mathrm{h}_{\text {in }}$ is the mean heat transfer coefficient inside the tubes in $\mathrm{KW} / \mathrm{m}^{2} \mathrm{~K}, \mathrm{~A}_{\text {tube }}$ is the tube surface area in $\mathrm{m}^{2}, \mathrm{~T}_{\text {tube }}$ is the outside surface temperature of the tube in $\mathrm{K}$, and $\mathrm{T}_{\mathrm{av}}$ is the average temperature of the flowing air inside the tube in $\mathrm{K}$.

Applying the conservation of energy principle, the heat balance equation can be expressed as (Zhihua Zhou, 2013)

$$
\mathrm{q}_{\text {conection-air }}=\mathrm{q}_{\text {solar }}-\mathrm{q}_{\text {emitted }}-\mathrm{q}_{\mathrm{c}}
$$


On other hand, to calculate the chimney height required to achieve the air flowing inside the tubes the following equation is used,

$$
\mathrm{H}=\frac{\Delta P l}{g(\rho a-\rho g)}
$$

Where $\mathrm{H}$ is the chimney height required to sustain air movement (m), $\Delta \mathrm{P}_{1}$ is the pressure loss inside the horizontal pipes $(\mathrm{Pa}), \rho a$ outdoor air density $\left(\mathrm{Kg} / \mathrm{m}^{3}\right), \rho g$ is the air density inside the pipes $\left(\mathrm{Kg} / \mathrm{m}^{3}\right)$, and $\mathrm{g}$ is the gravity which equals to $9.81\left(\mathrm{~m} / \mathrm{s}^{2}\right)$.

Pressure loss due to viscous effects in a circular cross section of pipe with length 1 can be calculated using the underneath Darcy Weisbach equation (Crowe, Elger, \& Roberson, 2005)

$$
\Delta \mathrm{P}=\frac{8 \mathrm{fl} Q^{2}}{\pi^{2} g d^{5}}
$$

Where, $\Delta \mathrm{P}$ is the pressure loss inside the horizontal pipes, 1 is the tube length in $\mathrm{m}, \mathrm{f}$ is a dimensionless parameter called the Darcy friction factor, resistance coefficient or simply friction factor (Incopera, 2002) and Q is the air flow rate inside the tubes in $\mathrm{m}^{3} / \mathrm{s}$.

The unknown parameters of equation number two are $\mathrm{Q}$ and $\Delta \mathrm{P}$; for friction factor (f) these values can be obtained from moody diagram.

\section{RESULTS AND DISCUSSION}

Through the day light an investigation of ASC using air as a working fluid and using an aluminum tubes embedded in an asphalt concrete material and a chimney of a PVC pipes was studied. The air velocities through the 
PVC chimney and the asphalt temperature have been taken to be used as an indicator for the energy gain by the asphalt.

As shown in Fig. 3a and 3b, for Aluminum pipes and 9 and $4 \mathrm{~m}$ chimney height, respectively, the temperature of the asphalt surface versus the temperature at chimney entrance is presented. From these figures it can be observed that the inlet air temperature at the entrance of the chimney $\mathrm{Ti}$ is always lower than the asphalt concrete surface temperature, Ts. This is because the portion of the heat loss by convection from the asphalt surface to the environmental air. In addition; a strong relation between asphalt surface temperature and chimney outlet air temperature has been observed as per the coefficient of determination $\left(\mathrm{R}^{2}\right)$ and an empirical equation connected between the two parameters has been formulated.

The ambient temperature versus the inlet temperature to the chimney, for the Aluminum pipes and $9 \mathrm{~m}$ and $4 \mathrm{~m}$ chimney height, respectively are shown in figures $4 \mathrm{a}$ and $4 \mathrm{~b}$. It is observed in these figures that, the inlet temperature to the chimney increased as the ambient temperature increases during the day light. Otherwise the average $\mathrm{T}_{\mathrm{i}}$ curves for the $9 \mathrm{~m}$ chimney height is always higher than the average $\mathrm{Ti}$ for the $4 \mathrm{~m}$ chimney height as shown in figures $4 \mathrm{a}$ and $4 \mathrm{~b}$. This is because as the chimney height increases the drafted air through the chimney increases causing the air velocity to increase. And as the air velocity increases the heat transfer between the inlet surface of the aluminum pipes and the flowing air inside increased causing the outlet air from the pipes to increase. To improve this phenomena the air velocity at the chimney outlet was measured as shown in figure 5. This figure represents the variation of the chimney outlet air velocity and the asphalt surface 
temperature for chimney heights 9 and $4 \mathrm{~m}$ during the day respectively. From this figure it is observed that the air velocity outlet from the chimney for $\mathrm{H}=9 \mathrm{~m}$ is higher than the air velocity outlet from the chimney for $\mathrm{H}=4 \mathrm{~m}$ at different asphalt surface temperature.

Generally, it can be noted from figures 3, 4 and 5 that the air inlet temperature to the chimney, $\mathrm{T}_{\mathrm{i}}$ and the outlet air from chimney is related with the asphalt surface temperature and ambient temperature.

Figures $6 \mathrm{a}$ and $6 \mathrm{~b}$ show the asphalt concrete surface temperature with time for chimney heights 9 and $4 \mathrm{~m}$ respectively. These curves represent the distribution of the average surface temperature of the asphalt concrete with time for two different heights of the chimney. From these figures it can be seen that for the air flow circulation through the asphalt and consequently the chimney heights has an effect on the surface temperature of the asphalt concrete. As shown from these figures that the average surface temperature of the asphalt concrete decreases with the increase of the chimney height as the air flow velocity through the ASC increase as presented in Figures $7 \mathrm{a}$ and 7b.Finally, it can be observed that as the drafted air flow through the asphalt concrete increases, the heat transfer by convection and radiation from the asphalt to the air will also increase.

For more clarifications of the results, the chimney efficiency versus its height has been studied at different asphalt surface temperatures as shown in Figure 8 . The efficiency of the chimney has been calculated through Equation 9 as conclude by (Alvaro García, 2014) 
$\eta=\frac{T c h-T a}{T i-T a}$

Where, $T_{c h}$ is the average temperature inside the chimney.

From this figure it can be observed that there is a very high effect of the asphalt surface temperatures on the chimney efficiency at different height of the chimney. The variation of the chimney efficiency reached $15 \%$ at $\mathrm{T}_{\mathrm{s}}$ equal to $50^{\circ} \mathrm{C}$. Moreover, it can be observed that as the chimney heights decrease the efficiency of the chimney decreases as well.

Figures $9 \mathrm{a}$ and $9 \mathrm{~b}$ represent the relation between asphalt surface temperature and wind speed for chimney heights equal to $9 \mathrm{~m}$ and $4 \mathrm{~m}$ respectively. From these figures it can be found that there is a very weak relation between the asphalt surface temperature and wind speed for these two chimney heights. On the other hand it can be observed that the outlet air velocity at asphalt surface temperatures $43,44{ }^{\circ} \mathrm{C}$ are less than the outlet air velocity at asphalt surface temperature equal to $40{ }^{\circ} \mathrm{C}$ for the two chimney heights as shown in figures 5 and 9. This is because at asphalt surface temperature equal to 43 and $44{ }^{\circ} \mathrm{C}$ the wind speed is higher than the one at 40 ${ }^{\circ} \mathrm{C}$ which results a resistance on the chimney exit flow rate causing a reduction in the air outlet velocity.

\section{CONCLUSION}

Environmental conditions and the prototype components have significant effect on prototype output in terms of the air velocity at the chimney exit. The following relationships have been determined using the prototype: 
1- Asphalt surface temperature has high effect on the chimney inlet air temperature.

2- Ambient temperature affects both the asphalt surface temperature, and chimney inlet temperature, i.e. if it increases both asphalt temperature and chimney inlet temperature increase.

3- A strong relation has been found between chimney height and outlet air velocity. As chimney height increases the outlet air velocity, from the ASC system increases.

4- In addition, the efficiency of the chimney was calculated in this investigation and effect of the chimney height and the asphalt surface temperature was reported. The efficiency was increased as the chimney height increased

In summary, it can be concluded that the ASC prototype performance for producing energy depends on prototype components in terms of chimney height, asphalt temperature and the environmental / atmospheric conditions in terms of ambient air temperature, and ambient wind speed. 


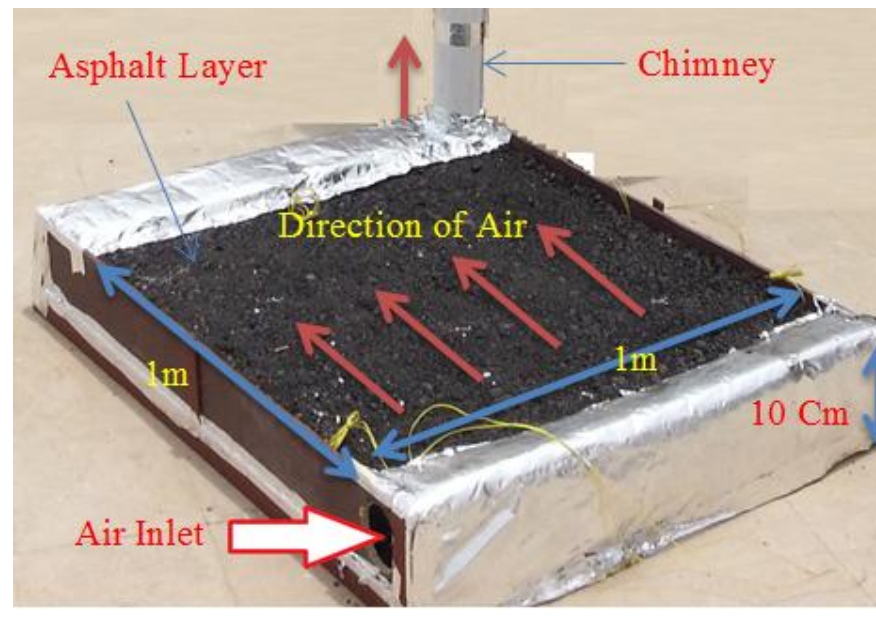

(a)

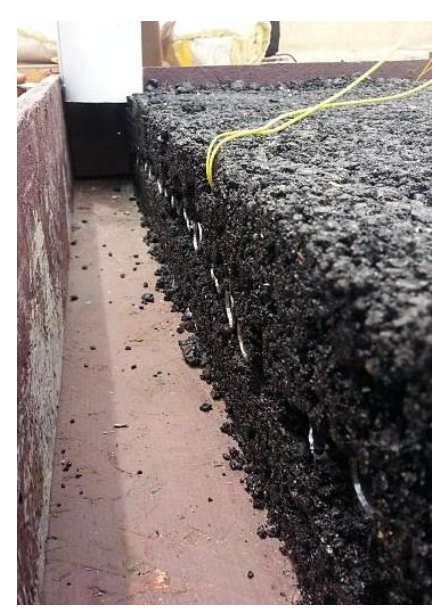

(b)

Fig(1): (a) Scheme of the test rig prototype. (b) Shape of the air pipes inside the asphalt concrete.

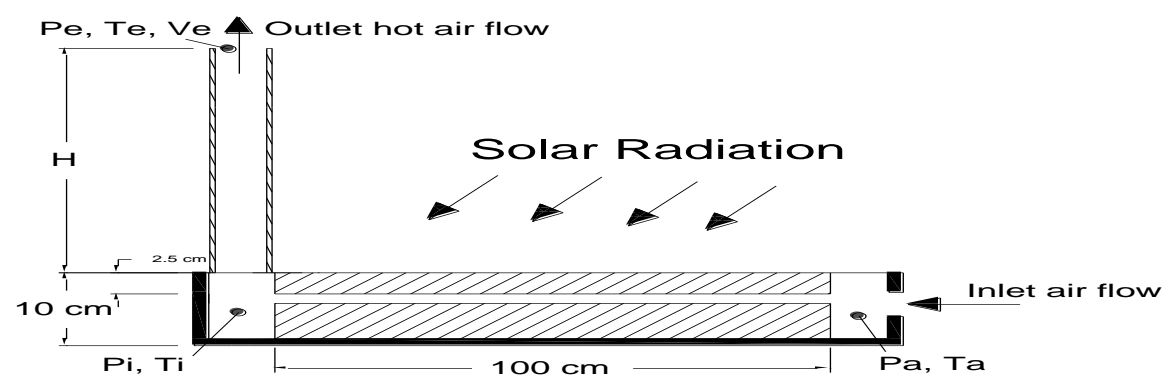

Fig(2): (a) Scheme of the prototype

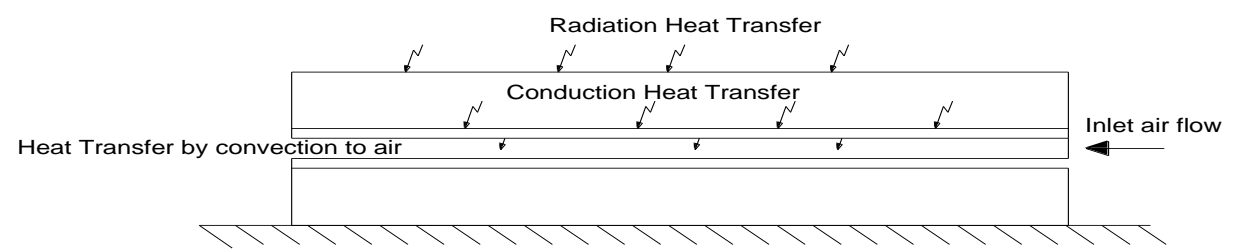

Fig(2): (b) Details of the heat transfer flow through the prototype

Fig(2): Test rig layout

Vol. 36, No.2, Dec. 2016 


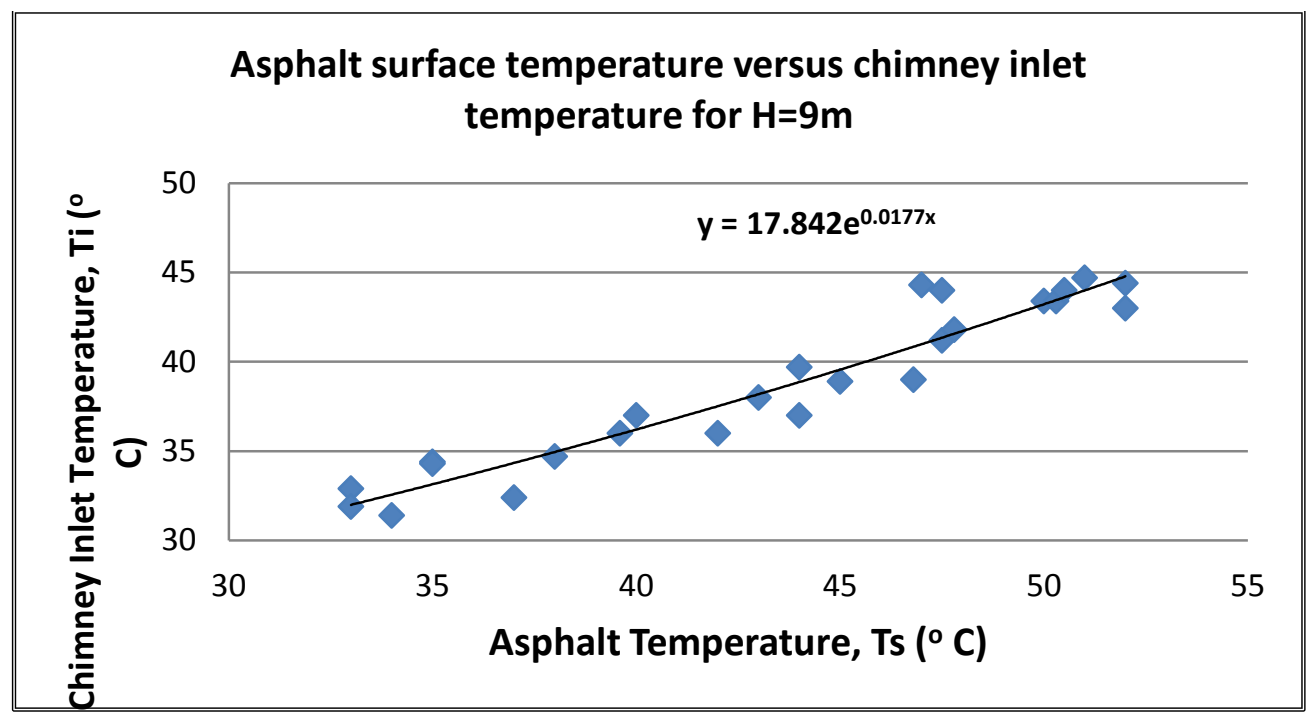

(a)

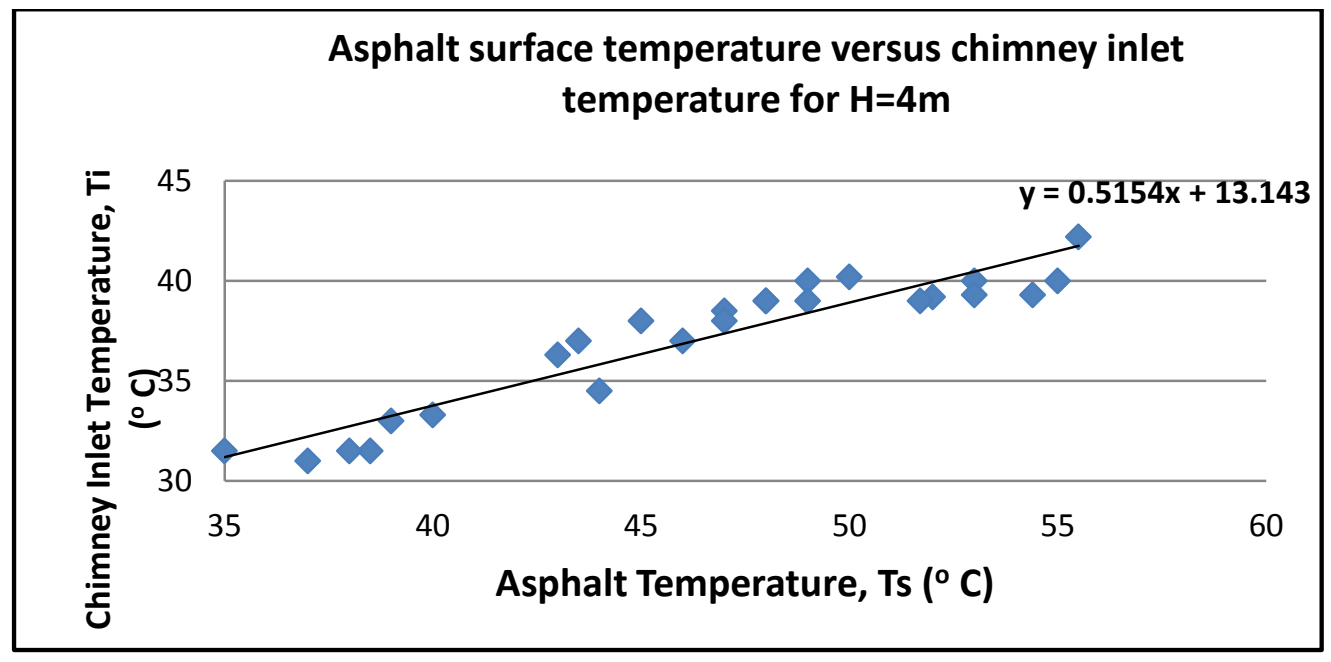

(b)

Fig(3): Asphalt surface temperature versus chimney inlet temperature 


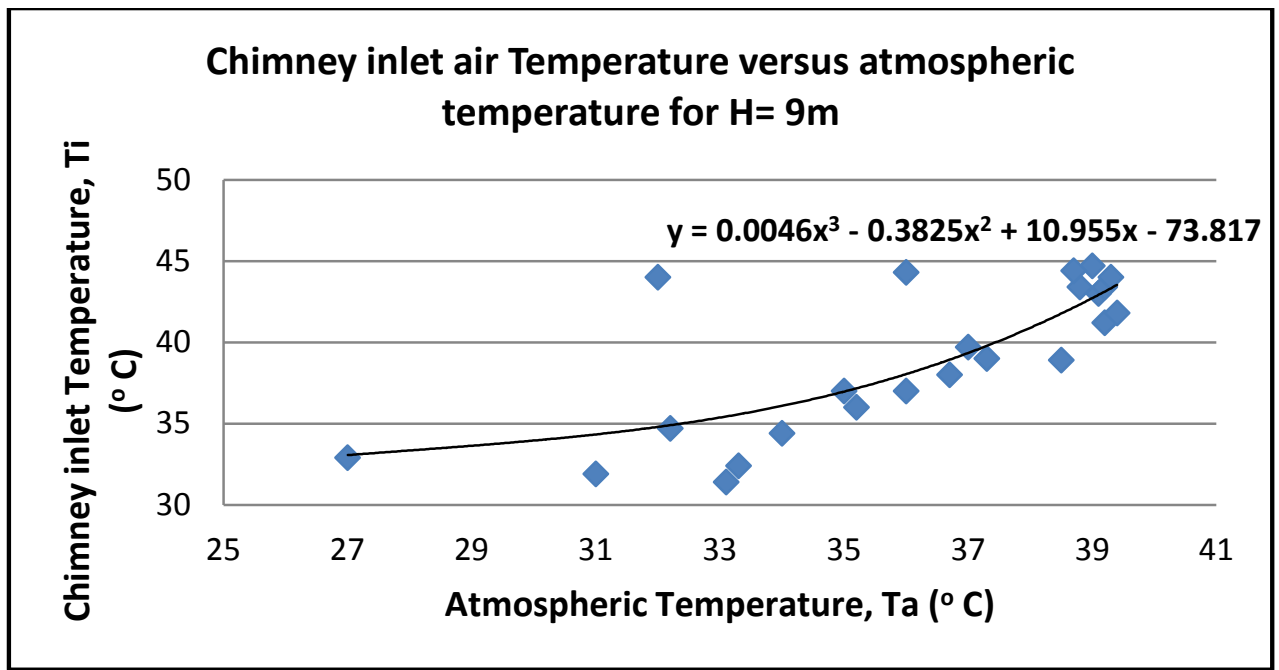

(a)

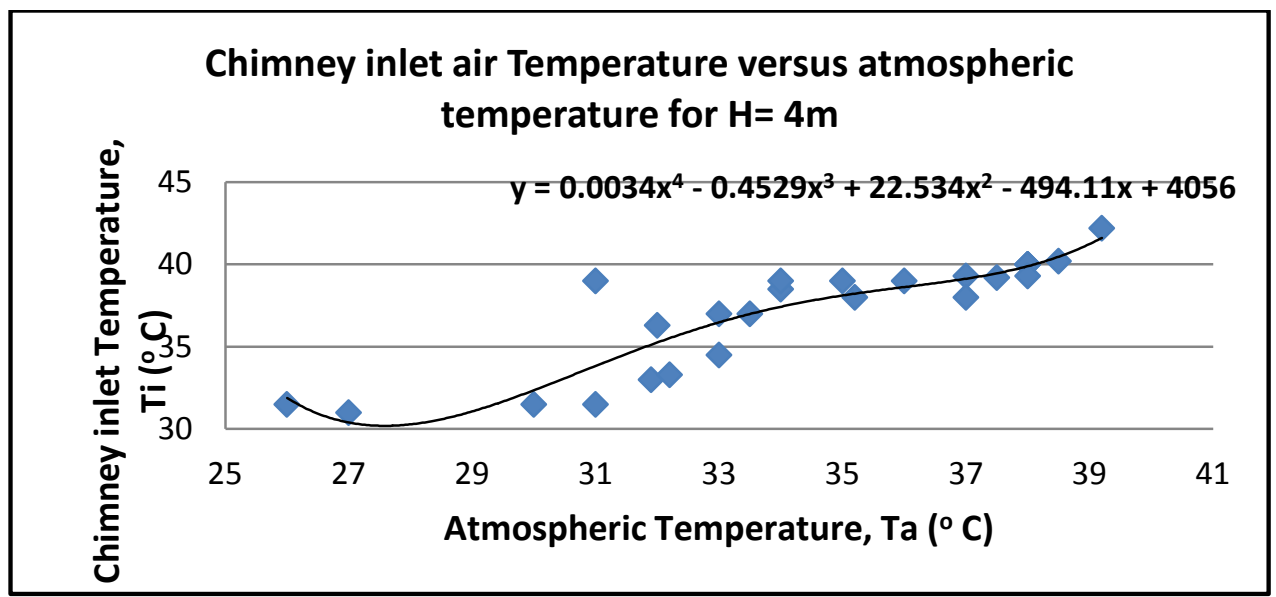

(b)

Fig(4): Ambient temperature, Ta Versus chimney inlet air temperature 
J. Environ. Sci.

Institute of Environmental Studies and Research - Ain Shams University

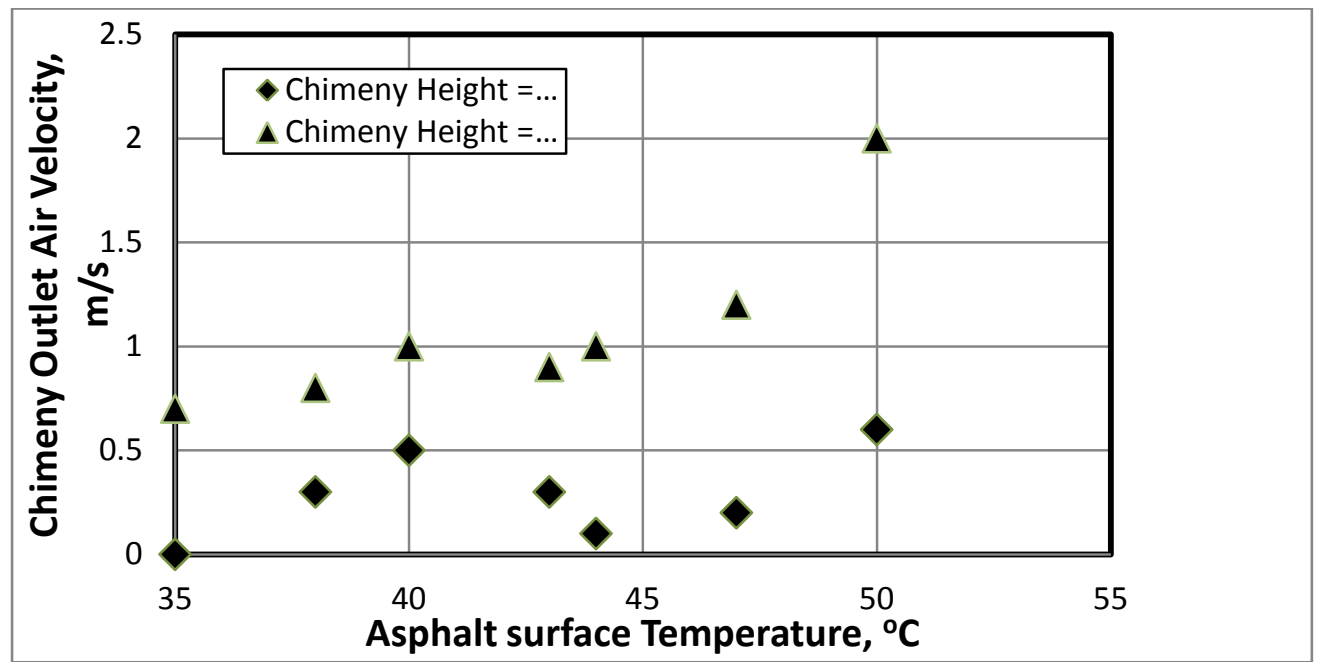

Fig(5): Chimney Outlet Air Velocity versus Asphalt surface temperature 


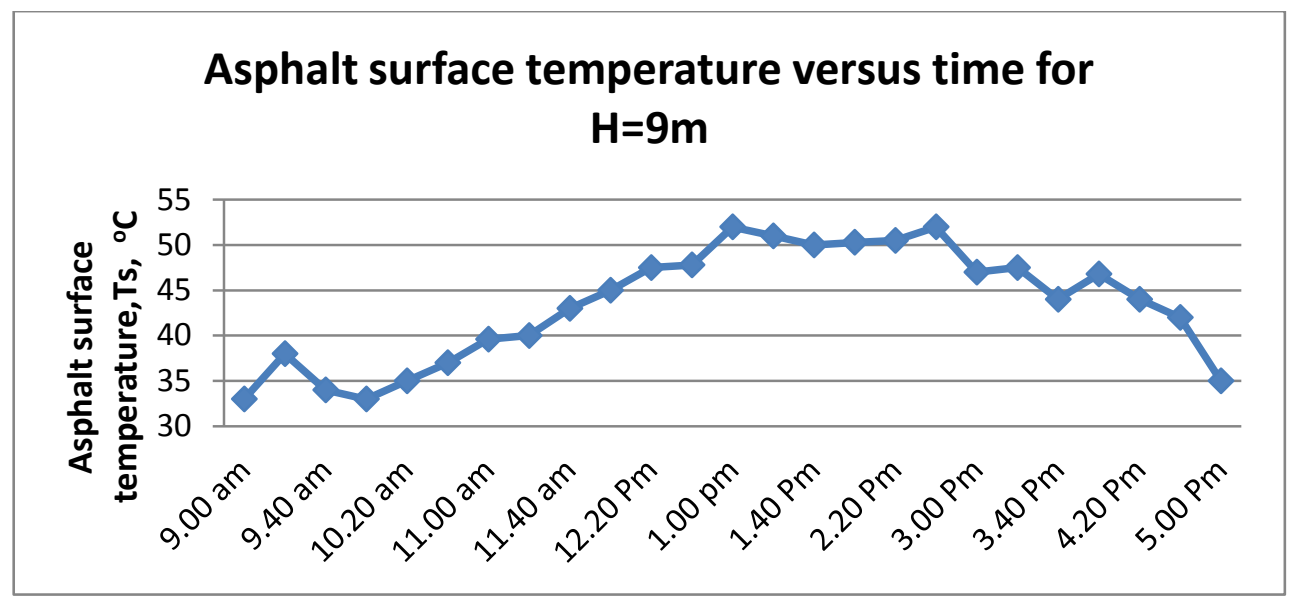

(a)

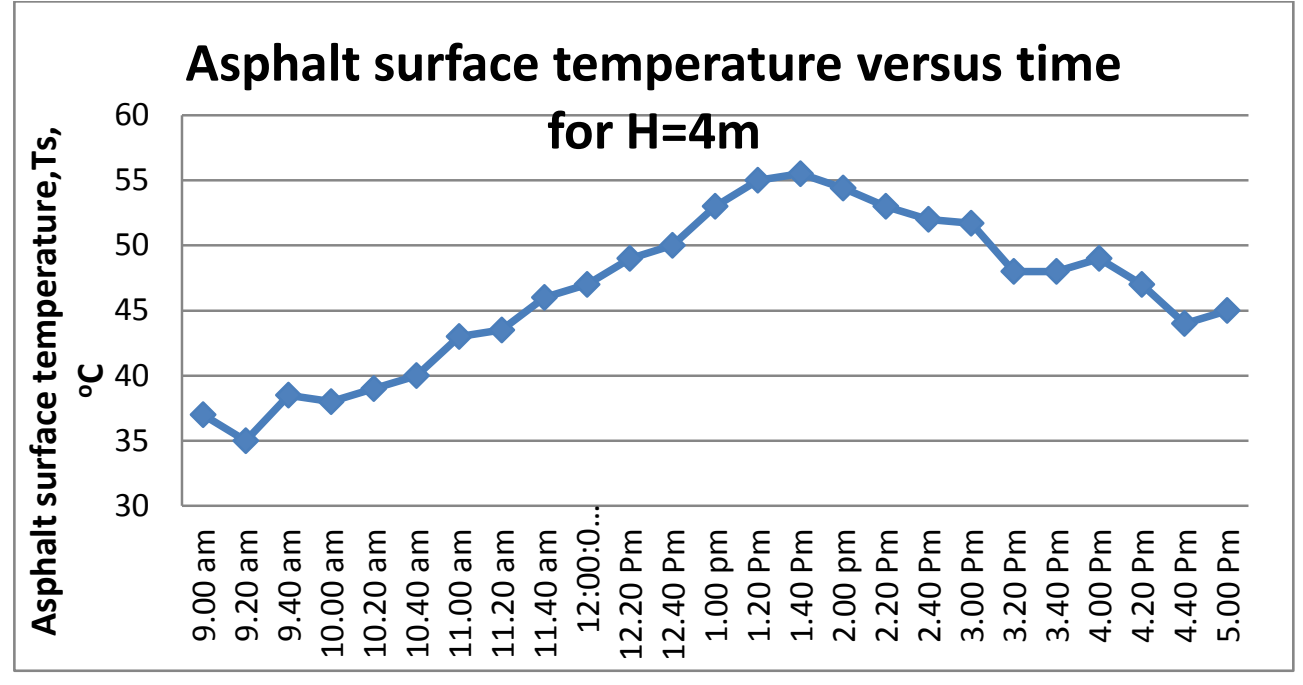

(b)

Fig.(6): Asphalt surface temperature versus time 


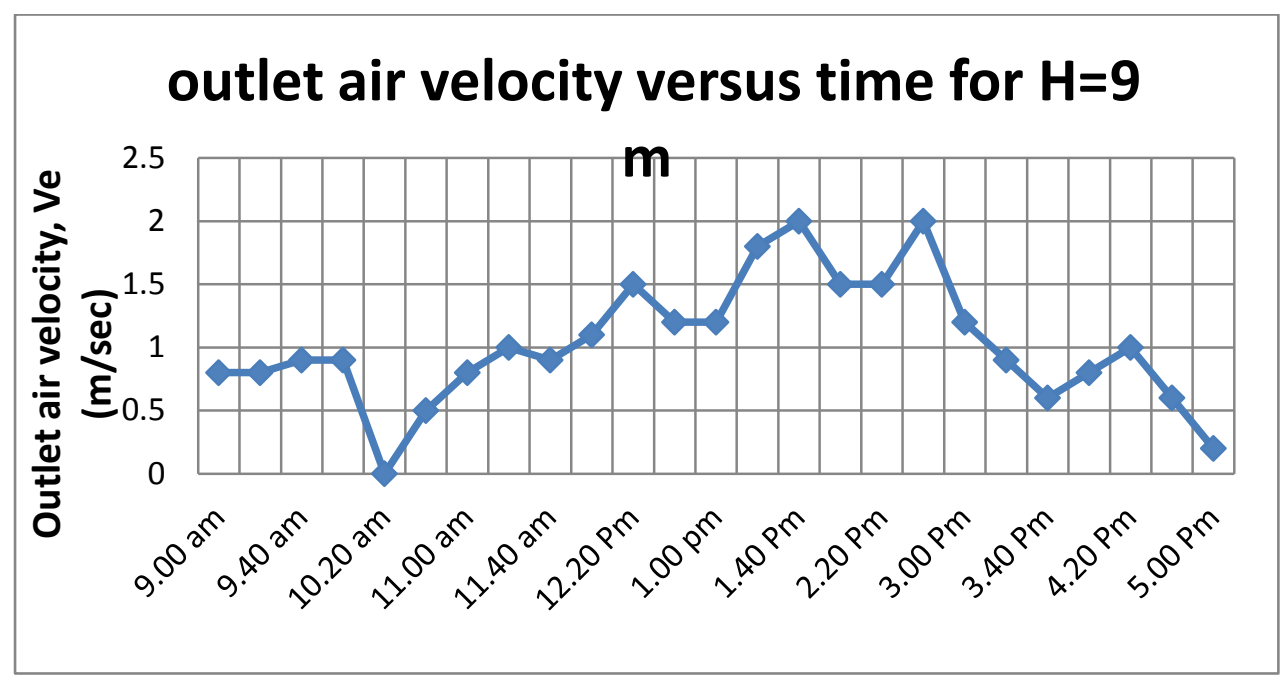

(a)

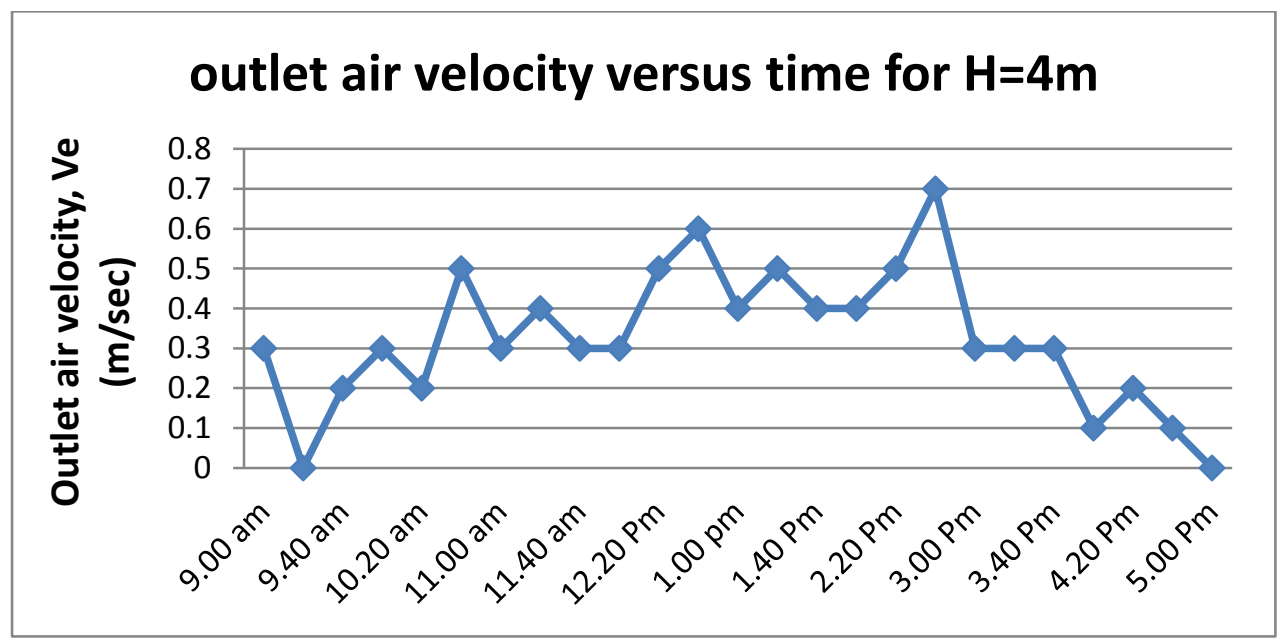

(b)

Fig(7): Outlet air velocity versus time 


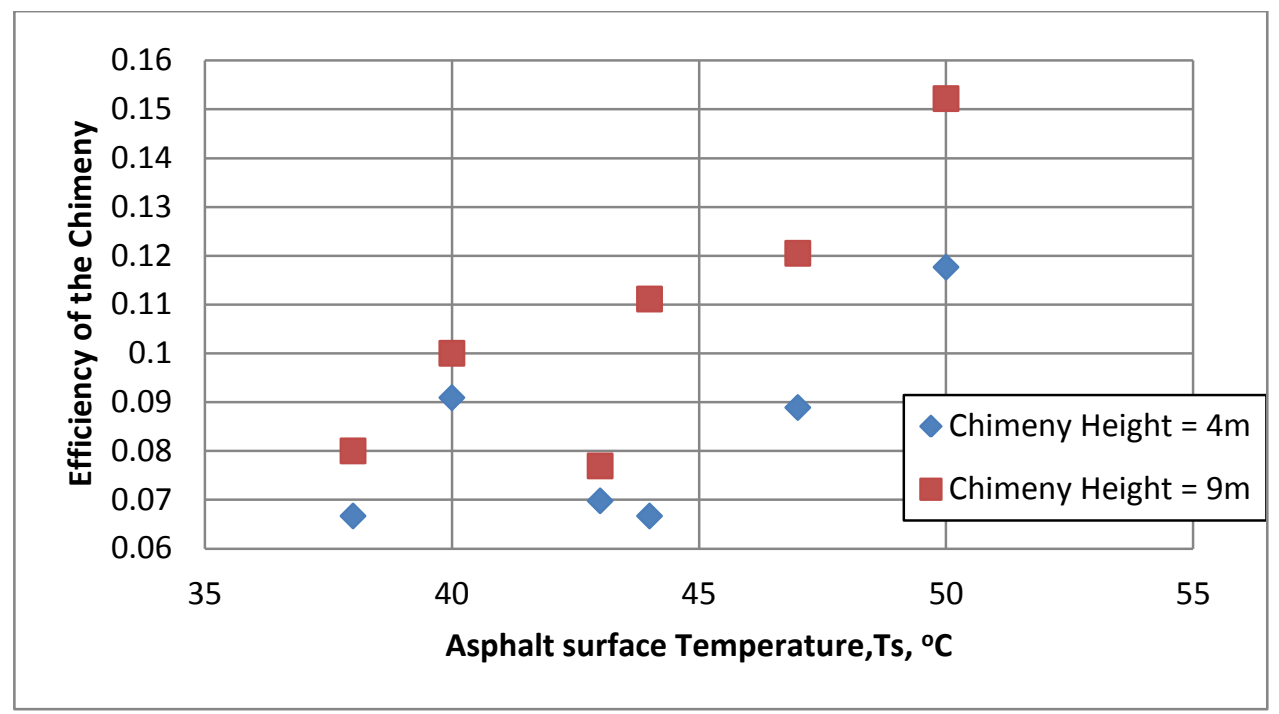

Fig(8): Efficiency of the chimney versus chimney height at different asphalt surface temperatures 


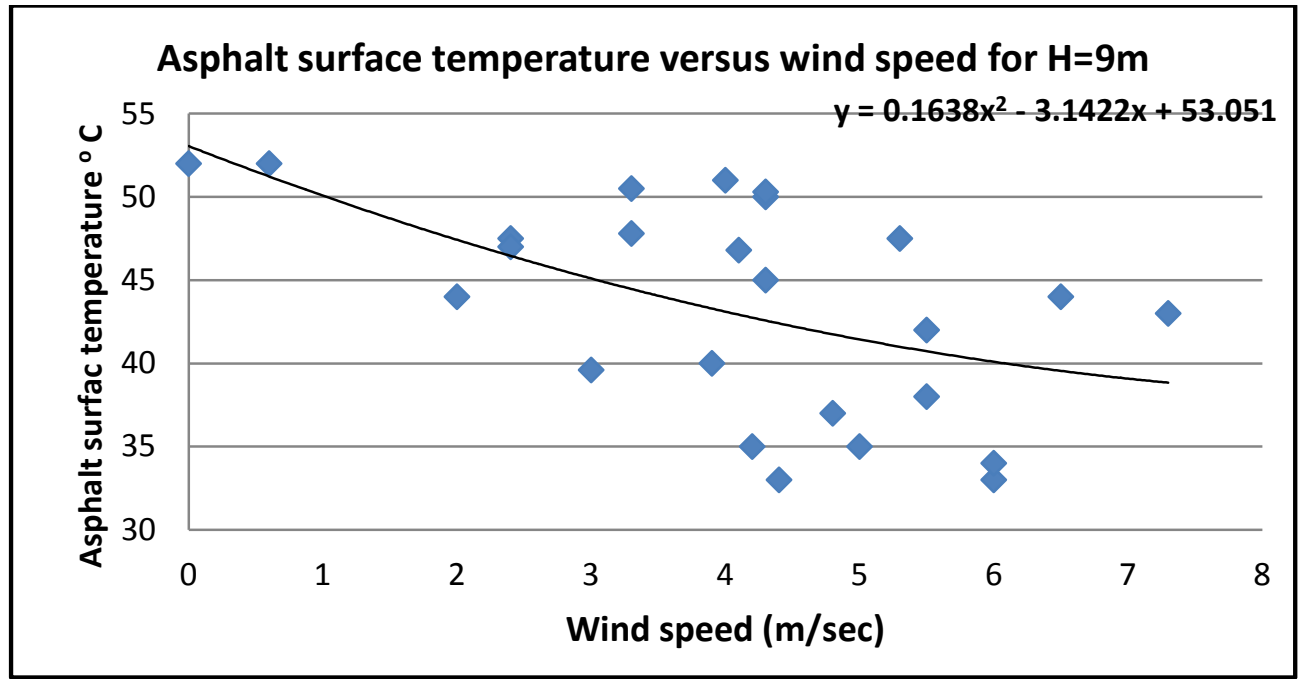

(a)

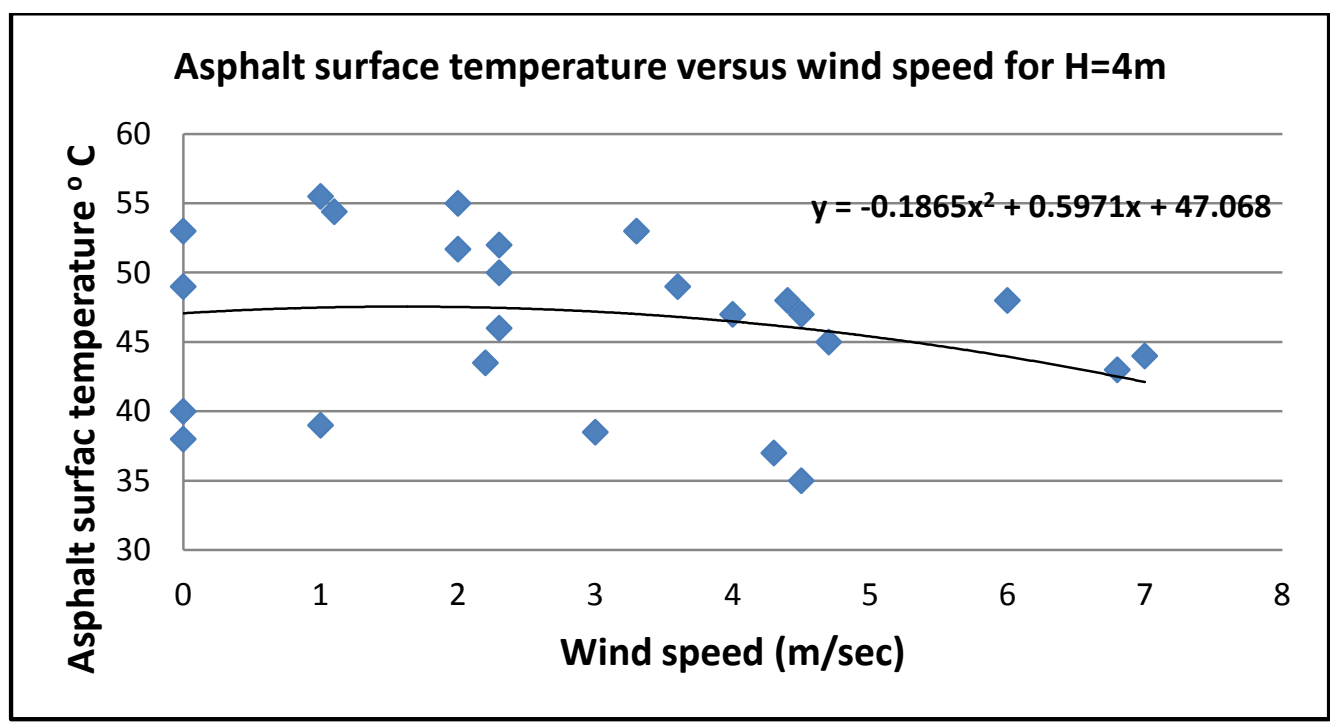

(b)

Fig.(9): Asphalt surface temperature versus wind speed 


\section{REFERENCES}

Alvaro García, M. N. (2014): How to transform an asphalt concrete pavement into a solar turbine. Applied Energy, $119: 431-437$.

Bobes-Jesus V, P.-M. P.-F.-H. (2012): Asphalt solar collectors: a literature review. Appl Energy, 12:12.

Crowe, C. T., Elger, D. F., \& Roberson, J. A. (2005): Engineering Fluid Mechanics (8th ed.). John Whiley\&Sons Inc.

Fluri, v. B. (2008): Performance analysis of the power conversión unit of a solar chimney power plant. Sol Energy, 82(11):999-1008.

Hsieh, C K, Q. C. (1989): Development of computer modelingfor prediction of temperature distribution inside concrete pavement. Florida: Finial Report to Florida Department of Transportation. Report.

Incopera, F. P. (2002): Transfer, fundamentals of heat and mass (5th ed.). John Wiley\&Sons Inc.

Al-Saad M.A. (1994): Development and testing of concrete solar collectors. International Journal of Solar Energy, 16(1), 16-27.

Mallick, RB, C. B. (2009): Reduction of urban heat island effect through harvest of heat energy from asphalt pavements. 2nd International conference on countermeasures to urban heat Islands.

Pascual-Munoz, P, C.-F. D.-B.-E. (2013): Thermal and hydraulic analysis of multi-layered asphalt pavements as active solar collectors. Appl Energy, 111:324-32.

Riain, NC, K. M. (1999): cooling effectiveness of soft facade passive stacks in a naturally ventilated office building. Case Study Indoor Built Environment.

Sakonidou, EP, K. T. (2008): Modeling of the optimum tilt of a solar chimney for máximum flow. Sol Energy, 82:80-94.

Shaopeng, Wu, Y. X. (2007): Utilization of steel slag as aggregates for stone mastic asphalt (SMA) mixtures. Building and Environment, 42(7): 2580-2585. 
Shouman, Enas, R. E. E. (2016): Economics Analysis of Diesel and Solar Water Pumping with Case Study Water Pumping for Irrigation in Egypt. International Journal of Applied Engineering Research, 11(2): 950-954.

Simulation, H. A. (2007): Model for calculating pavement temperature including maximum temperature.

Journal of the Transportation Research Board, 1699: 134-141.

Sullivan, C. G. (2007): Energy from asphalt pavements. Sustainable construction materials and technologies. Coventry: UW Milwaukee CBU. (pp. 45-53)

Wang, H, W. S. (2010): Numerical simulation on the thermal response of heat-conducting asphalt pavements. Phys Scripta,139: 13901:14041.

Zhihua Zhou, S. H. (2013): Characteristics and application of road absorbing solar. Front. Energy, 7(4) :525-534. 


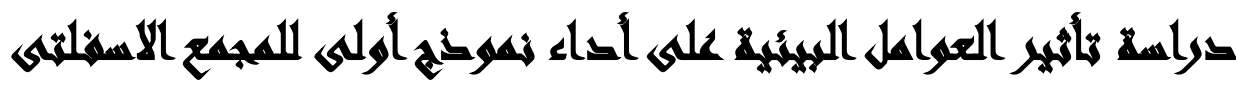

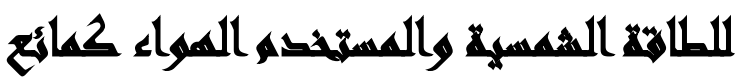

[v]

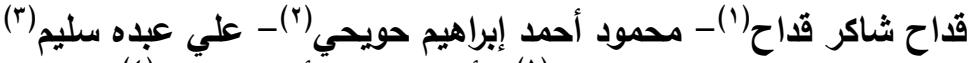

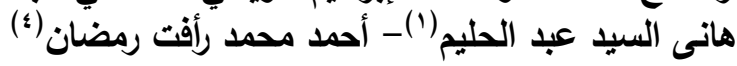

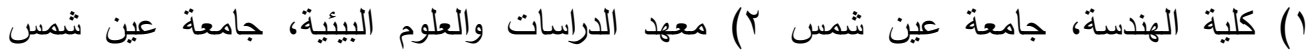
r) وزارة النقل ع ) شركه رشيد للبترول والغاز

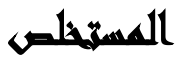

نقص الوقود الأحفوري الَّهم الباحثين البحث فى مصادر الطاقة المتجددة. ومشكلات الجزيرة

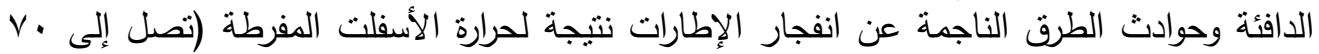

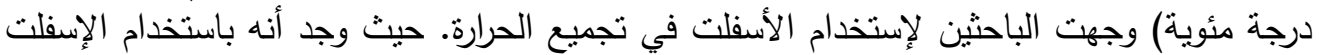

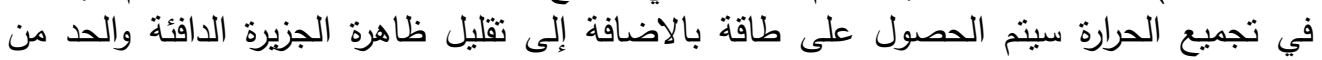

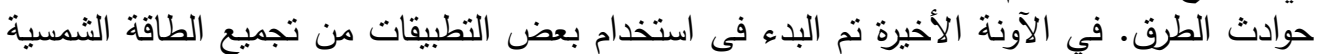

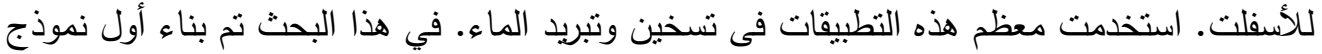

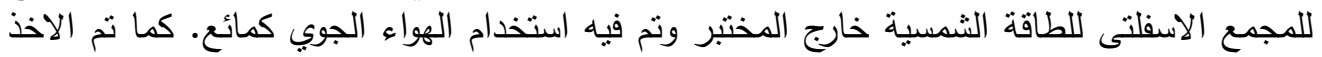

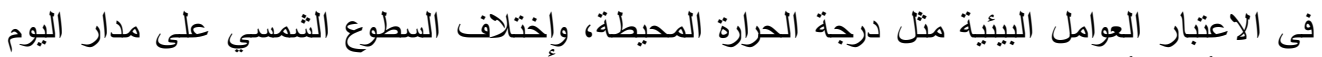

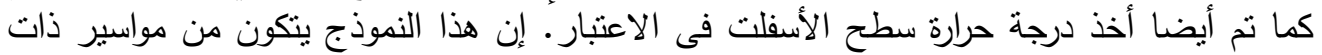

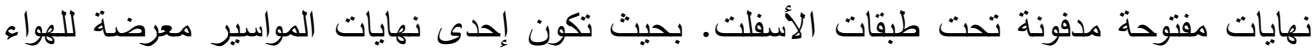

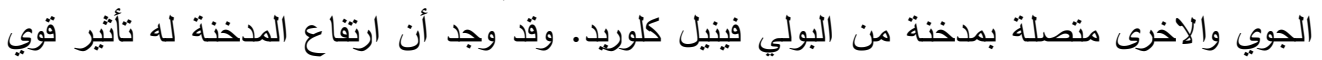

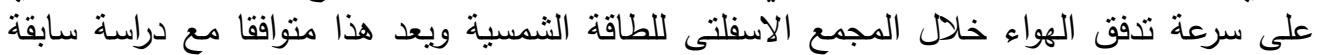

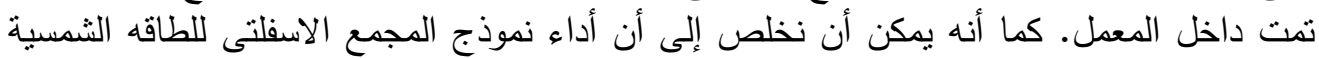

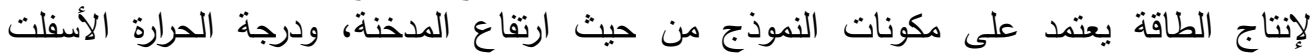
والظروف البيئية / الجوية من حيث درجة حرارة الهواء المحيط، وسرعة الرياح المحيطة. 